\title{
Nutrient enrichment of cassava peels using a mixed culture of Saccharomyces cerevisae and Lactobacillus spp solid media fermentation techniques
}

\author{
Ganiyu Oboh \\ Biochemistry Department \\ Federal University of Technology \\ P.M.B. 704 \\ Akure, Ondo state \\ Nigeria \\ Tel: 2348035600192 \\ E-mail: goboh2001@yahoo.com
}

Financial support: Federal University of Technology, Akure, Nigeria's Senate Research Grant Number URG/MINOR/99/142.

Keywords: cassava peels, cyanide, fermentation, protein.

Cassava pulp was fermented with pure strains of Saccharomyces cerevisae and two bacteria namely Lactobacillus delbruckii and Lactobacillus coryneformis for 3 days. The squeezed liquid from the fermented pulp was used to ferment cassava peels for 7 days. Analysis of the dried fermented peels revealed that there was a significant $(P<0.05)$ increase in the protein content of the cassava peels fermented with squeezed liquid from the inoculated cassava pulp $(21.5 \%)$ when compared with the unfermented cassava peel (8.2\%). Moreover, the treatment equally brought about a significant $(P<$ $0.05)$ decrease in the cyanide $(6.2 \mathrm{mg} / \mathrm{kg})$ and phytate content (789.7 $\mathrm{mg} / 100 \mathrm{~g})$ when compared with the unfermented cassava peels, which had $44.6 \mathrm{mg} / \mathrm{kg}$ cyanide and $1043.6 \mathrm{mg} / 100 \mathrm{~g}$ phytate. The fermented cassava peels could be a good protein source in livestock feeds.

Fermentation is one of the oldest applied biotechnologies, having been used in food processing and preservation as well as beverages production for over 6,000 years (Motarjemi, 2002). The fermentation process of staples serves as a means of providing a major source of nourishment for large rural populations, and contributes significantly to food security by increasing the range of raw materials which can be used in the production of edible products (Adewusi et al. 1999). Fermentation enhances the nutrient content of foods through the biosynthesis of vitamins, essential amino acids and proteins, by improving protein quality and fibre digestibility. It also enhances micronutrient bioavailability and aids in degrading antinutritional factors (Achinewhu et al. 1998).

Two important biological wastes, that may cause damage to environment, are generated during the traditional processing of cassava starchy storage roots for gari production in Africa, namely, the cassava peels and the liquid squeezed out of the fermented parenchyma mash. Cassava peels derived from gari processing are normally discarded as wastes and allowed to rot in the open, thus resulting in health hazards. As a rough estimate, about 10 million tonnes of cassava are processed into gari annually in Nigeria alone. Since these peels could make up to $10 \%$ of the wet weight of the roots, they constitute an important potential resource for animal feeds if properly processed by a bio-system (Antai and Mbongo, 1994). The peels contain toxic levels of cyanogenic glucosides, while the liquid

Table 1. Proximate composition of fermented cassava peel (\% dry weight). Protein content of the waste water from inoculated fermented cassava pulp was $3.8 \mathrm{mg} / \mathrm{ml}$.

\begin{tabular}{|l|c|c|c|c|c|c|}
\hline \multicolumn{1}{|c|}{ Sample } & Ash & Moisture & Protein & Fat & Crude fibre & Carbohydrate \\
\hline Inoculated fermented & $7.2^{\mathrm{a}} \pm 0.2$ & $6.4^{\mathrm{a}} \pm 0.4$ & $21.5^{\mathrm{a}} \pm 1.2$ & $2.1^{\mathrm{b}} \pm 0.1$ & $11.7^{\mathrm{a}} \pm 0.5$ & $51.1^{\mathrm{b}} \pm 0.4$ \\
\hline Naturally fermented & $6.0^{\mathrm{b}} \pm 0.2$ & $5.7^{\mathrm{b}} \pm 0.2$ & $11.1^{\mathrm{b}} \pm 0.3$ & $3.5^{\mathrm{a}} \pm 0.2$ & $6.5^{\mathrm{b}} \pm 0.5$ & $67.3^{\mathrm{a}} \pm 0.4$ \\
\hline Unfermented & $6.4^{\mathrm{b}} \pm 0.4$ & $5.1^{\mathrm{c}} \pm 0.3$ & $8.2^{\mathrm{c}} \pm 0.1$ & $3.1^{\mathrm{a}} \pm 0.4$ & $12.5^{\mathrm{a}} \pm 0.2$ & $64.6^{\mathrm{a}} \pm 0.2$ \\
\hline
\end{tabular}

Values with the same alphabet along the same column are not significantly different $(P>0.05)$.

Values are mean \pm S.E $(n=3)$. 
Oboh, G.

contains a heavy load of microorganisms capable of hydrolyzing the glucosides. The resulting products of fermentation of cassava peels with squeezed out water can be dried and used as animal feeds (Tweyongyere and Katongole, 2002). This study therefore sought to investigate the effect of the fermentation of cassava peel on the nutritional quality of the fermented product.

\section{MATERIALS AND METHODS}

\section{Materials}

Sweet variety of Cassava tubers (less than $50 \mathrm{mg} / \mathrm{kg}$ cyanide content) was freshly harvested from the Research farm of the Federal University of Technology, Akure, Nigeria. The chemicals used were of analytical grade, and glass distilled water was used. The microorganisms were collected from Federal Institute of Industrial Research Oshodi (FIIRO), Lagos, Nigeria.

\section{Methods}

Sample preparation. There were two treatments carried out in three replicates each. In the first treatment, whole roots were peeled, washed, grated, after which $1 \mathrm{~kg}$ of the processed pulp was spread in a tray (about $50 \mathrm{~cm}$ diameter) to an average layer thickness of $2 \mathrm{~cm}$, a $10 \mathrm{~g}$ mixture of freshly sub-cultured pure strains of Lactobacillus delbruckii, Lactobacillus coryneformis and Saccharomyces cerevisae (2:1:1) was carefully added to the solid matrix in order to obtain a well homogenized mixture. The mash was allowed to ferment for three days; the incubation temperature and the relative humidity of the air were $30^{\circ} \mathrm{C}$ and $90-93 \%$. After the fermentation the waste-water was pressed out, while the second treatment was fermented naturally without any inoculum. $150 \mathrm{ml}$ of the wastewater was carefully mixed with $200 \mathrm{~g}$ of washed, dried and ground cassava peels, the mash was subsequently spread in a tray to an average thickness of about $2 \mathrm{~cm}$ and allowed to ferment for seven days, the incubation temperature and the relative humidity of the air were $30^{\circ} \mathrm{C}$ and $90-93 \%$. The fermented peels were subsequently analyzed. Unfermented peels served as control.

Sample analysis. The nutritional composition (ash, fat and crude fibre) of the fungi/bacterial fermented cassava product was evaluated using the methods reported by Cordenunsi et al. 2004 and the protein content was determined using the micro-Kjeldhal method ( $\mathrm{N}$ x 6.25).
The phytate content was determined, based on the ability of standard ferric chloride to precipitate phytate in dilute $\mathrm{HCl}$ extracts of the sample (Preet and Punia, 2000). The cyanide content of the fermented cassava peels was determined by silver nitrate titration (Oboh et al. 2002). The $\mathrm{Zn}, \mathrm{Na}, \mathrm{Ca}$, and $\mathrm{K}$ contents were determined on aliquots of the solutions of the ash by established flame atomic absorption spectrophotometry procedures using a Perkin-Elmer atomic absorption spectrophotometer (Model 372).

Analysis of data. The results are presented as the mean standard values of three replicates each. A one-way analysis of variance (ANOVA) and the Least Significance Difference (LSD) were carried out. Significance was accepted at $P \leq 0.05$.

\section{RESULTS AND DISCUSSION}

There was a significant increase $(P<0.05)$ in the protein content of the cassava peels fermented with waste-water from fermented cassava pulp (Table 1). This increase was highest in the peel fermented with waste-water from the inoculated cassava pulp (21.1\%). The increase in the protein content of the cassava peels fermented with waste water from the inoculated fermented cassava pulp could be attributed to the possible secretion of some extracellular enzymes (proteins) such as amylases, linamarase and cellulase (Oboh and Akindahunsi, 2003) into the cassava mash by the fermenting organisms in an attempt to make use of the cassava starch as a source of carbon (Raimbault, 1998). Apart from this, the increase in the growth and proliferation of the fungi/bacterial complex in the form of single cell proteins may possibly account for the apparent increase in the protein content of the peels fermented with waste water from the inoculated fermented cassava pulp (Antai and Mbongo, 1994; Obohet al. 2002). In view of this significantly enhanced protein content in the fermented cassava peels, the cassava peels, regarded as having no economic value, could be integrated into animal nutrition provided the cassava peel is acceptable and highly digestible in farm animals.

There was a significant decrease $(P<0.05)$ in the carbohydrate content of the cassava peels fermented with waste water from the inoculated cassava pulp, when compared to the unfermented (Table 1). The decrease could be attributed to the ability of the fungi/bacterial complex to hydrolyze starch into glucose and ultimately the glucose will be used by the same organisms as a carbon source to

Table 2. Mineral composition of fermented cassava peel (ppm dry weight).

\begin{tabular}{|l|c|c|c|c|}
\hline Sample & $\mathbf{C a}$ & $\mathbf{N a}$ & $\mathbf{K}$ & $\mathbf{Z n}$ \\
\hline Inoculated fermented & $0.03^{\mathrm{a}} \pm 0.00$ & $0.04^{\mathrm{a}} \pm 0.00$ & $0.05^{\mathrm{a}} \pm 0.00$ & $0.01^{\mathrm{a}} \pm 0.00$ \\
\hline Naturally fermented & $0.03^{\mathrm{a}} \pm 0.00$ & $0.04^{\mathrm{a}} \pm 0.00$ & $0.06^{\mathrm{a}} \pm 0.00$ & $0.01^{\mathrm{a}} \pm 0.00$ \\
\hline Unfermented & $0.03^{\mathrm{a}} \pm 0.00$ & $0.04^{\mathrm{a}} \pm 0.00$ & $0.05^{\mathrm{a}} \pm 0.00$ & $0.01^{\mathrm{a}} \pm 0.00$ \\
\hline
\end{tabular}

Values with the same alphabet along the same column are not significantly different $(P>0.05)$.

Values are mean \pm S.E $(n=3)$. 
synthesize fungi/bacterial biomass rich in protein. The proportionate increase in the protein content in peels fermented with waste water from the inoculated cassava pulp could also account for the decrease in the carbohydrate content (Obohet al. 2002). There was no discernable trend in the fat, crude fibre, ash (Table 1) and the mineral content of the cassava peels (Table 2).

Cassava peels usually have higher concentration of cyanogenic glucosides than the parenchyma (pulp); this makes the peel unsuitable as animal feed. Fermentation of the cassava peels with waste water from the fermented cassava pulp significantly reduced $(P<0.05)$ the cyanide content of the cassava peels $(6.2-23.5 \mathrm{mg} / \mathrm{kg})$, when compared with the unfermented cassava peels which had $44.6 \mathrm{mg} / \mathrm{kg}$ cyanide content. However, the cassava peels fermented with waste water from cassava pulp fermented with a mixture of Saccharomyces cerevisee, Lactobacillus delbruckii and Lactobacillus coryneformis had a significantly lower $(P<0.05)$ cyanide content $(6.2 \mathrm{mg} / \mathrm{kg})$ than those cassava peels fermented with waste water from the naturally fermented cassava pulp that had $23.5 \mathrm{mg} / \mathrm{kg}$ cyanide content.

The cyanide concentration in the cassava peels fermented with waste-water from fermented cassava pulp was low, when compared with the usual cyanide content of cassava products in Nigeria [19.0 mg/kg (gari), $25 \mathrm{mg} / \mathrm{kg}$ (fufu)], and that of the cyanide content of some micro-fungi fermented cassava products $(9.1-17.2 \mathrm{mg} / \mathrm{kg})($ Oboh et al. 2002; Oboh and Akindahunsi, 2003). This shows that the microorganisms in the waste water were capable of partially degrading cyanogenic glucosides and the breakdown products (Tweyongyere and Katongole, 2002).

It is also evident from the results that waste-water from the inoculated cassava pulpwas very efficient in cyanide detoxification than that of naturally fermented cassava. The cassava peels fermented with waste-water from the inoculated cassava products could be considered safe in terms of cyanide poisoning in view of the fact that the cyanide was below the deleterious level of $30 \mathrm{mg} / \mathrm{kg}$ (Tweyongyere and Katongole, 2002).

There was a significant decrease $(P<0.05)$ in the phytate content of the fermented cassava peels (705.1 - 789.7 $\mathrm{mg} / 100 \mathrm{~g}$ ). This decrease was more significant in cassava peels fermented with waste water from naturally fermented cassava pulp $(705.13 \mathrm{mg} / 100 \mathrm{~g})$. The unfermented cassava peels had $1043.56 \mathrm{mg} / 100 \mathrm{~g}$ phytate content (Table 3). The decrease in the phytate content of the fermented cassava peel could be attributed to possible secretion of the enzyme phytase by the microorganisms in the waste-water. This enzyme is capable of hydrolysing phytate thereby decreasing the phytate content of the fermented cassava peels. The variation in the level of decrease in the phytate content of the products by each waste water indicated that the enzyme activity varies with organism (Oboh et al. 2003). It would appear from the result that the phytase in wastewater from the naturally fermented cassava productshad the highest activity.

Table 3. Antinutrient composition of fermented cassava peel (dry weight).

\begin{tabular}{|l|c|c|}
\hline \multicolumn{1}{|c|}{ Sample } & Cyanide $(\mathbf{m g} / \mathbf{k g})$ & Phytate $(\mathrm{mg} / \mathbf{1 0 0 g})$ \\
\hline Inoculated fermented & $6.2^{\mathrm{a}} \pm 0.3$ & $789.7^{\mathrm{b}} \pm 0.2$ \\
\hline Naturally fermented & $23.3^{\mathrm{b}} \pm 0.2$ & $705.1^{\mathrm{c}} \pm 0.2$ \\
\hline Unfermented & $44.6^{\mathrm{a}} \pm 0.2$ & $1043.6^{\mathrm{a}} \pm 0.1$ \\
\hline
\end{tabular}

Values with the same alphabet along the same column are not significantly different $(P>0.05)$. Values are mean $\pm \operatorname{S.E}(n=3)$.

In view of the increase in protein content of the cassava peels fermented with waste-water from fermented cassava products (inoculated and natural) and the significant decrease $(P<0.05)$ in the antinutrients (residual cyanide and phytate), this by-product could be a good supplement in compounding animal feed provided that it is acceptable and highly digestible.

\section{REFERENCES}

ACHINEWHU, S.C.; BARBER, L.I and IJEOMA, I.O. Physicochemical properties and garification (gari yield) of selected cassava cultivars in Rivers State, Nigeria. Plant Foods for Human Nutrition, June 1998, vol. 52, no. 2, p. 133-140.

ADEWUSI, S.R.; OJUMU, T.V. and FALADE, O.S. The effect of processing on total organic acids content and mineral availability of simulated cassava-vegetable diets. Plant Foods for Human Nutrition, December 1999, vol. 53, no. 4, p. 367-380.

ANTAI, S.P. and MBONGO, P.M. Utilization of cassava peels as substrate for crude protein formation. Plant Foods for Human Nutrition, December 1994, vol. 46, no. 4, p. 345-51.

CORDENUNSI, B.R.; DE MENEZES WENZEL, E.; GENOVESE, M.I.; COLLI, C.; DE SOUZA GONCALVES, A. and LAJOLO, F.M. Chemical composition and glycemic index of Brazilian pine (Araucaria angustifolia) seeds. Journal of Agricultural and Food Chemistry, June 2004, vol. 52, no. 11, p. 3412-3416.

MOTARJEMI, Y. Impact of small scale fermentation technology on food safety in developing countries. International Journal of Food Microbiology, May 2002, vol. 75 , no. 3 , p. $213-229$.

$\mathrm{OBOH}, \mathrm{G}$. and AKINDAHUNSI, A.A. Biochemical changes in Cassava products (flour \& gari) subjected to Saccharomyces cerevisae solid media fermentation. Food Chemistry, September 2003, vol. 82, no. 4, p. 599-602. 
Oboh, G.

OBOH, G.; AKINDAHUNSI, A.A. and OSHODI A.A. Dynamics of Phytate-Zn balance of Fungi Fermented Cassava products (Flour \& Gari). Plant Foods for Human Nutrition, September 2003, vol. 58, no. 3, p. 1-7.

OBOH, G.; AKINDAHUNSI, A.A. and OSHODI, A.A. Nutrient and anti-nutrient content of Aspergillus niger fermented cassava products (flour and gari). Journal of Food Composition and Analysis, October 2002, vol. 15, no. 5, p. 617-622.

PREET, K. and PUNIA, D. Proximate composition, phytic acid, polyphenols and digestibility (in vitro) of four brown cowpea varieties. International Journal of Food Science and Nutrition, May 2000, vol. 51, no. 3, p. 189-193.

RAIMBAULT, M. General and microbiological aspects of solid substrate fermentation, Electronic Journal of Biotechnology [online], 15 December 1998, vol. 1, no. 3 [cited 28 August 2001]. Available from: http:/www.ejbiotechnology.info/content/vol1/issue3/full/9/ 9.PDF. ISSN 0717-3458.

TWEYONGYERE, R. and KATONGOLE, I. Cyanogenic potential of cassava peels and their detoxification for utilization as livestock feed. Veterinary and Human Toxicology, December 2002, vol. 44, no. 6, p. 366-369. 